\title{
História das mulheres, história de vida de professoras: elementos para pensar a docência ${ }^{1}$
}

\section{Women's history, life histories of teachers: elements to think about teaching}

\author{
Sônia Maria da Silva Araújo²
}

\begin{abstract}
RESUMO
Por meio da história de vida de duas professoras ribeirinhas, reflete-se sobre a docência que acontece no contexto do arquipélago de Guajará, em Belém do Pará, Brasil. Traços comuns entre as histórias, como violência sexual na infância, pobreza e escolarização são destacados para demonstrar que a docência não pode ser pensada fora do contexto mais amplo de constituição da mulher. Argumenta-se que a condição da mulher na região historicamente conformou possibilidades singulares que explicam como e porque meninas que foram por muito tempo alijadas do mundo da escola se transformam em professoras. Demonstra-se como ser professora se articula aos processos societais do espaço ribeirinho, assegurando todo um processo de inter-relação.

Palavras-chave: história das mulheres; história de professores; docência.
\end{abstract}

\begin{abstract}
Through two life histories of riverine teachers, this article reflects on teaching that happens in the context of Guajará Archipelago, in Belém of Pará, Brazil. It points out common features between those life histories as sexual violence during childhood, poverty, and schooling in order to demonstrate that teaching cannot be thought out of a wider context of women's constitution.
\end{abstract}

DOI: $10.1590 / 0104-4060.37341$

$1 \mathrm{O}$ projeto referente a este artigo recebeu financiamento do Conselho Nacional de Desenvolvimento Científico e Tecnológico do Brasil (CNPq), Edital Gênero MCT/CNPq/SPM-PR/MDA $\mathrm{N}^{\circ} 57 / 2008$.

2 Universidade Federal do Pará. Belém, Pará, Brasil. Instituto de Ciências da Educação, Programa de Pós-Graduação em Educação. Av. Augusto Correa, nº 01. Bairro: Guamá. CEP: 66075110. 
It argues that the women status in this region has historically performed singular possibilities that explain how and why girls who were excluded from the school world for a long period turned into teachers. It demonstrates how being a teacher joins to the social processes of the riverine space, ensuring a whole interrelation process.

Keywords: women's history; life histories of teachers; teaching.

\section{Introdução}

Este artigo faz parte de um projeto de pesquisa empírica, desenvolvido entre os anos 2009-2011, que objetivava compreender a constituição da professora ribeirinha na Amazônia paraense para indicar o sentido das relações de gênero nesse processo, que remonta a um tempo para além do seu presente imediato. Duas questões nortearam a investigação: como meninas, transformadas em mulheres, historicamente alijadas do mundo da escola, passam a assumir a função como professoras nos espaços ribeirinhos da região amazônica? De que modo ser professora se articula aos processos societais que o espaço ribeirinho amazônico precisou historicamente constituir?

Pautamos o estudo na história cultural e metodologicamente na reconstituição da memória pela oralidade. Inicialmente mapeamos a região, localizamos as escolas e identificamos as professoras. Posteriormente, após um longo processo de aproximação, aplicamos formulário a todas as docentes e, em seguida, escolhemos quatro (das oito cujas histórias de vida estão ligadas ao espaço insular de Belém) para realizar entrevistas livres. Neste artigo, apresentamos e analisamos duas histórias que revelam pontos de interseção com as histórias de vida da maioria das professoras daquele lugar e que nos ajudam a pensar criticamente sobre a docência de um modo geral.

\section{Bases teóricas da investigação}

A pesquisa visou abordar três temáticas inter-relacionadas: cultura, gênero e formação de professoras, isto porque em outras pesquisas realizadas identificamos no conjunto de práticas de professoras situadas em espaços ribeirinhos e campesinos da Amazônia paraense modos de atuação em que a formação es- 
colar (inicial e continuada), ainda que importante, não era capaz de explicá-las. Supúnhamos que tais modos decorriam das histórias sociais regionais destas professoras e de como a sua condição de mulher foi sendo tecida no contexto dessas histórias.

Constatado isto, passamos a realizar, do ponto de vista temático, estudos sobre a mulher no interior e nos sertões do Brasil e verificamos que grande parte dos trabalhos produzidos, pautados em uma interpretação crítica da realidade, aponta para a necessidade de se pensar o trabalho, as atividades profissionais realizadas pela mulher em meio a histórias particulares de sobrevivência e superação para que novas representações possam ser constituídas. No contexto da análise desses estudos percebemos que as interpretações sobre a mulher construídas por autoras rompiam com um certo silêncio instaurado pelos discursos científicos dos homens sobre as mulheres ${ }^{3}$.

Em síntese, os dados apresentados em pesquisas sobre a condição e a luta das mulheres em espaços não urbanos, especialmente no interior da Amazônia paraense, ratificam a ideia já apreendida pelos/as historiadores/as das mulheres de que elas não são uma categoria homogênea e indicam que é preciso compreender a pluralidade de vidas vividas por grupos de mulheres nessas realidades. A história da mulher, como nos esclarece Joan Scott (1992, p. 65), requer um relato mais complexo.

\section{Breve incursão sobre as professoras das ilhas e suas condições de possibilidades}

As professoras que participaram do estudo atuam na região de ilhas de Belém, capital do estado do Pará, segunda cidade mais populosa da região Norte e a maior região metropolitana da Amazônia. A cidade tem cerca de 1.393.399 habitantes (IBGE, 2012) e é formada pelo arquipélago de Guajará, composto por 42 ilhas e ilhotas, sendo 39 habitadas. A Belém insular totaliza uma área

3 A história escrita pelos homens, como já denunciaram as feministas, omitiu o lugar ocupado pelas mulheres nos acontecimentos. Esta omissão só começa a ser superada com a nova história, especialmente com a obra "A história das mulheres do Ocidente, da Antiguidade até nossos dias", organizada por George Duby e Michelle Perrot (1991), e com "As mulheres ou os silenciamentos da história", de Perrot (2005). Nessas obras evidencia-se que as mulheres não são nem passivas, nem submissas. Como assevera Perrot, "a miséria, a opressão, a dominação, por mais reais que sejam, não bastam para contar a sua história" (2005, p. 152). As mulheres, para esta autora, foram se apropriando de campos de trabalho e, nessa direção, rompendo com limites impostos à (e pela) ordem social. 
territorial de $69,42 \%$ do município. A população que ocupa a parte insular é de aproximadamente 38.590 habitantes (BELÉM, 2006).

Por meio do formulário aplicado na primeira etapa da investigação foi possível conhecer os espaços das ilhas e ter acesso a informações essenciais para o curso da pesquisa. O formulário contemplava a obtenção dos seguintes dados: 1) pessoais e socioeconômicos; 2) profissionais; 3) escolarização; 4) docência; 5) lazer e atividades culturais. As respostas obtidas foram tabuladas em quadros e colocadas em gráficos.

As ilhas possuíam até 2012 um total de 27 professoras $^{4}$ que atuava na educação infantil e anos iniciais do Ensino Fundamental. O formulário foi aplicado a todas elas. Após a tabulação dos dados constatamos que de um modo geral as professoras se encontravam em uma faixa etária que ia dos 24 aos 50 anos de idade: $44 \%$ solteiras, $41 \%$ casadas, $11 \%$ divorciadas e $4 \%$ viúvas. Mais do que a metade contava com a ajuda de membros familiares no orçamento da casa, entre estes: mãe, marido, irmão, tio, ex-marido e avós. Quase a metade do número de professoras era responsável pela maior renda familiar. As profissões dos companheiros dessas mulheres variavam entre lavrador, carpinteiro, extrativista e pescador. Dessas mulheres, $86 \%$ moravam em casa própria e possuíam entre 4 e 7 eletrodomésticos. A média de filhos era de 1 a 6 , com idades que iam dos 2 aos 24 anos.

Em relação ao processo de escolaridade grande parte estudou em instituição pública, tanto no Nível Fundamental quando Superior, e as dificuldades vividas para conseguir dar continuidade aos estudos ao longo da vida foram muitas, como veremos nas histórias de vida a serem apresentadas a seguir. Do conjunto dessas professoras, $71 \%$ possuíam ensino médio com formação pedagógica e $29 \%$, curso superior. $86 \%$ cursaram todo o Ensino Fundamental em escola pública; apenas $14 \%$ estudaram parte em escola pública e parte em escola privada. Quanto ao ensino médio, todas o cursaram em escola pública.

Sobre as dificuldades para se escolarizar as professoras atribuem à escassez de barcos, livros e apoio da família; falta de escolas e de dinheiro; desemprego; moradia na casa de parentes e/ou conhecidos; falta de energia elétrica, e ter que cedo trabalhar para se sustentar. A maior parte não almejava essa profissão e dizia não ter realizado seu sonho profissional, mesmo as que já atuavam no magistério há mais de 11 anos. Elas explicam que seguiram esta profissão por falta de outras oportunidades e de incentivo por parte da família e da escola;

4 Esse número é sempre muito fluido. As professoras das ilhas, na sua maioria, não são concursadas e as vagas nas escolas são utilizadas pelo poder público como recurso político, o que faz com que ele disponha do remanejamento e mesmo da dispensa dessas professoras segundo os seus interesses. 
por começarem a trabalhar cedo e por falta de dinheiro para investir em uma "profissão melhor". Todavia, afirmaram gostar da profissão e disseram que ser professora, no conjunto da família, é muito dignificante. Além de contribuir no orçamento da casa, o exercício da profissão é motivo de admiração no meio familiar, entre amigos e conhecidos. A docência entre essas professoras é uma profissão exercida por outros membros da família, que acabam por facilitar seu ingresso na atividade e contribuir no aprimoramento da profissão: 74\% disseram haver outros/as professores/as na família. Mas a profissão docente não é uma "herança" de pai ou mãe. Grande parte tem pais com baixo nível de escolaridade. Em geral os parentes que exercem a docência são membros de sua geração: primos/as e irmãos/ãs.

\section{Histórias de vida de professoras ribeirinhas}

Com o objetivo de dar voz às mulheres professoras da região de ilhas de Belém do Pará procuramos contar histórias que outros deixaram de "lembrar". Nessa perspectiva, nos aproximamos dos propósitos de Michelle Perrot (2005), que ao contar as histórias dos excluídos (operários, mulheres e prisioneiros da Europa) traz à superfície a história dos silenciados. Esta autora, em seus estudos sobre as mulheres, expressa o desejo de inverter as perspectivas historiográficas tradicionais e mostrar a presença real das mulheres na história mais cotidiana; um tipo de revalidação da história das mulheres. Inspiradas em Perrot, fomos conhecer as histórias de vida das professoras das ilhas que lá nasceram, residem e que continuam a manter vínculo familiar e cultural com esse espaço. Contaremos a história de Hortência e Rosa ${ }^{5}$.

\section{A história de Hortência}

Hortência tem 31 anos, é solteira e trabalha há 2 (dois) anos nas Unidades pedagógicas de Castanhal de Mari-Mari e Caruaru' ${ }^{6}$ localizadas na ilha de Mosqueiro, onde nasceu. Neta de pescador, com renda familiar em torno de 2

5 Os nomes identificados são fictícios.

6 Castanhal de Mari-Mari e Caruaru são duas comunidades rurais, localizadas no interior da Ilha. 
(dois) a 3 (três) salários mínimos, sustenta a casa junto com a mãe, aposentada, que estudou até a $5^{\mathrm{a}}$ série do Ensino Fundamental, e também nasceu e viveu na ilha trabalhando como empregada doméstica. O pai nasceu em Belém, possui o curso médio completo em topografia, mas nunca teve contato com a filha.

Hortência trabalhou em outras escolas na Ilha e diz sentir-se realizada na profissão. Tem curso superior completo em Pedagogia adquirido na instituição particular Universidade Vale do Acaraú (UVA), mas fez todo o Ensino Fundamental em escola pública. Lamenta não poder se aprofundar nos estudos pela falta de transporte para deslocamento e condições de acesso a livros e à internet. Revela que sempre quis ser professora como a irmã, que há 11 (onze) anos atua na profissão e que considera a profissão de professora muito dignificante. Atribui a importância de seu ofício especialmente ao fato de poder ensinar a sua mãe a ler e interpretar. Para ela, ser professora sempre vale a pena porque "apesar das dificuldades existentes tudo vale a pena pelos alunos".

Hortência foi criada, como ela mesma diz, a vida toda só pela mãe. Aos 5 (cinco) anos de idade a mãe conseguiu um emprego na praia como servente de barraqueiro. Ela destaca que a mãe foi adotada pela avó e que esta, por sua vez, não a aceitava. Diz Hortência (2010): "ela judiava de mim; ela me judiava muito, não gostava de mim por eu ser morena". Além disso, segundo Hortência, a mãe era casada antes de tê-la e do casamento gerou 4 (quatro) filhos, que a avó sempre aceitou porque eram originários de uma relação civil legítima. As duras memórias de infância de Hortência revelaram que sofreu abuso sexual.

Depois da violência sexual sofrida, Hortência passou a ir junto com a mãe para o seu trabalho e retornava para casa de madrugada, numa bicicleta. Mas só foi a partir daí que Hortência passou a ter contato com outras crianças, a se sentir mais livre, apesar do sofrimento - pois diz "eu sempre soube o que foi sofrer, sempre soube o que foi sofrer nessa vida" -, a ter contato com outras pessoas e superar o medo dos adultos.

Esta situação nova, de mais acolhimento, ocorreu depois que a mãe de Hortência foi trabalhar como doméstica na casa de uma família (que frequentava a barraca onde a mãe trabalhava como servente de barraqueiro) e passou a morar lá. Nesse momento já estava com 10,11 anos de idade. Na casa desta família, que a tratava muito bem, ela diz (2010): "lá, eu pude ter uma infância que eu nunca tive, brinquedos que eu nunca tive, que a própria Dona Lúcia com Seu Carlos ${ }^{7}$ me davam, né? Saíam comigo, não tinham vergonha de mim, mesmo sendo brancos".

Após a morte do Sr. Carlos, D. Lúcia deixou a ilha de Mosqueiro e foi para Belém. É só neste momento que passa a frequentar a escola. Com apro-

7 Lúcia e Carlos são nomes fictícios, usados para ocultar a identidade dos sujeitos citados. 
ximadamente 10 anos de idade ela faz o jardim de infância e a alfabetização, momento em que sua irmã mais velha já era professora de uma escola pública da Ilha. Quando já cursava a $6^{\mathrm{a}}$ série, a irmã frequentemente se ausentava das atividades docentes para se qualificar em Belém e Hortência assumia algumas de suas tarefas, especialmente a de correção das provas dos alunos.

Hortência inicia então o ensino médio em Magistério e assume uma turma na Escola em que sua irmã trabalhava, em substituição a uma professora que teve que se afastar. Três meses depois, em 2001, já estava com uma turma de alfabetização. Depois disso, com o ensino médio completo, tenta ingressar no ensino superior. Fez vestibular para a Universidade Federal do Pará (UFPA) e para a Universidade do Estado do Pará (Uepa), mas não logrou sucesso. Diante da dificuldade em ingressar numa universidade pública, faz o curso de Pedagogia da UVA, o que lhe custou a demissão do colégio porque a congregação religiosa que mantinha a Escola só queria compor o seu quadro com professores/as formados/as em universidades públicas ou na Universidade da Amazônia (Unama) ${ }^{8}$. Depois disto, passou cinco anos sem trabalhar, de 2002 a 2007. Neste ínterim, dedicou-se a atividades na igreja (católica) da ilha.

Hortência (2010) conta em detalhes a dificuldade em conseguir uma vaga de professora na região: "Tinha terminado em 2005 [o curso superior], mesmo assim eu não consegui, né? Não consegui emprego. Levava, cansei de levar [o currículo] na $\mathrm{Semec}^{9}$, cansei de levar em todo canto de escola, mas sempre queriam Uepa, Federal ou Unama".

Depois de muito tentar, conseguiu ser contratada pela Semec para atuar nas comunidades rurais de Caruaru e Castanhal de Mari-Mari ${ }^{10}$, que já conhecia pelo trabalho de catequista que lá realizava. Ao assumir sua primeira turma constatou tratar-se de uma classe multiciclo, realidade que desconhecia. Reuniam-se crianças de $1^{\mathrm{a}}$ a $4^{\mathrm{a}}$ série e Hortência não sabia como lidar com a turma. Com a ajuda de outras colegas, e do próprio Coordenador, foi superando as dificuldades.

8 A Unama é uma universidade particular sediada em Belém, considerada de qualidade superior às universidades particulares que se instalaram no estado sem qualquer infraestrutura e base docente fixa.

9 Secretaria Municipal de Educação do Município de Belém.

10 Para atuar em Castanhal de Mari-Mari, Hortência tem que enfrentar uma trilha mata adentro. Nas infindáveis vezes que atravessou o caminho se deparou com o perigo de ser atacada por animais silvestres e peçonhentos, além de ter que enfrentar o medo produzido pelos mitos do lugar e que fazem parte do imaginário simbólico das comunidades de Castanhal de Mari-Mari e Caruaru, como o mito da Mãe d'Água, da Mantinta Pereira, da Pedra do Neguinho, do Curupira e do Olho D’Água. Segundo Galvão (1976), essas entidades míticas são partes constituintes da região amazônica e resultam do amálgama das tradições ibéricas e ameríndias. Para Figueiredo (1994), tais entidades não guardam mais as funções indígenas, pois foram reformuladas pela influência do catolicismo, dos cultos afro-brasileiros e outros, oriundos do contato dessas populações interioranas com as frentes pioneiras de penetração nacional. 
O orgulho que Hortência tem em trabalhar naquelas comunidades (Caruaru e Castanhal de Mari-Mari) é de impressionar. Ela confessa que quando lá começou a trabalhar, por meio das atividades da igreja, assumiu o compromisso de que só sairia daquele lugar depois de aposentada. Ela analisa: "pra cá, pra cidade [está falando da vila do Mosqueiro, centro urbano da Ilha], eu não queria, porque o trabalho lá é muito mais gratificante do que aqui na cidade; porque os pais lá, eles reconhecem muito mais o trabalho do professor, reconhecem mais o avanço do filho do que numa cidade" (HORTÊNCIA, 2010).

Para Hortência a escola realiza um trabalho que se expande para o âmbito da comunidade, onde as relações com os pais são mais próximas, o que a torna mais eficiente ao ajudar o professor a encontrar soluções adequadas para os problemas. Também considera que sua atuação na comunidade favorece a escola. Ela, por exemplo, já constatou a necessidade de se implementar à noite, com a máxima urgência, uma turma de EJA; verificou que as crianças não conseguem avançar nos estudos porque os pais têm um nível muito baixo de escolarização.

Hortência também tem uma formação adicional interessante. Ela fez o curso de monitora de música no Conservatório Carlos Gomes ${ }^{11}$, onde estudou teoria musical, aprendeu a fazer leitura de partitura e a tocar flauta doce. Esta formação, aliada à catequese e ao envolvimento com as tradições da comunidade (imaginários e festas), fez com que ela tivesse uma relação de grande envolvimento com a cultura local. Como integrante da comunidade não deixa de participar de nenhuma festa, nem de acreditar nos imaginários que fazem parte do universo simbólico do lugar. A vivência que tem com as tradições a torna uma pessoa articuladora das práticas culturais e do que elas podem render financeiramente para a comunidade e orientá-la nas benfeitorias comuns e na ajuda particular de seus membros.

Todavia, a instabilidade no emprego (já que não é concursada) a atormenta, pois sonha em passar num concurso público da Semec e deixar de ser prestadora, mas, como o concurso é muito difícil, ela "entrega tudo na mão de Deus". A formação judaico-cristã de Hortência se estende para o modo como ela se comporta diante das injustiças e da exploração de seu trabalho quando diz que "Deus sabe o que faz" e que é preciso sempre "dar a outra face". A postura resignada se concretiza quando assume: "eu agradeço muito a Deus; eu não reclamo de nada". Este modo de lidar com as situações nas quais é penalizada se materializa sempre que compara o presente com o passado, quando este último parece pesar ainda mais sobre seus ombros. A infância de maus-tratos, a violência sofrida e as privações impostas ao serem comparadas com o presente a fazem

11 Instituição estadual de formação de músicos, mantida pela Fundação Carlos Gomes. 
ver as dificuldades do presente sempre de forma diminuta e as oportunidades como uma dádiva de Deus.

O profundo conhecimento que Hortência diz ter da comunidade se converte em orgulho. Ela faz questão de sempre destacar que usa esse conhecimento em sala de aula; que é capaz de "aproveitar" este conhecimento em favor do aprendizado das crianças, da realização de uma prática docente concreta, articulada à vida vivida pelas crianças naquele espaço insular. A agricultura, o cultivo de frutas do lugar, a pesca, o artesanato, o vocabulário e o imaginário são sempre reapropriados em sala de aula. Não por acaso, Hortência (junto com outra colega de trabalho) é responsável pelo único documento escrito sobre as comunidades de Castanhal de Mari-Mari e Caruaru, resultado de um trabalho pedagógico da escola que envolveu as comunidades.

\section{A história de Rosa}

Rosa tem 39 anos e é evangélica, casada com um operador de máquinas. Está no seu segundo casamento. A renda familiar mensal, da qual ela é a maior responsável, varia entre 4 (quatro) e 6 (seis) salários mínimos. Mora em casa própria e possui eletrodomésticos básicos como fogão, geladeira e máquina de lavar roupa. Também possui um computador (ainda que este não lhe ofereça acesso à internet) e telefone celular. Tem 3 (três) filhos com as seguintes idades: 20 (vinte), 17 (dezessete) e 6 (seis) anos.

Rosa nasceu no município de Barcarena, interior do estado do Pará; a mãe e o pai nasceram em Belém. A mãe tem o Ensino Fundamental completo e o pai o Ensino Fundamental incompleto. O pai era pescador e a mãe também pescava e trabalhava na agricultura familiar. Sua educação escolar aconteceu sob a orientação dos pais e de tios.

Professora da unidade pedagógica da Ilha de Jamaci, Rosa também não é concursada da rede pública municipal de ensino e já trabalhou em todas as unidades pedagógicas de ilhas vinculadas administrativamente à Funbosque, isto é: Faveira, Seringal, Flexeira, Jutuba I e II. Formada em Pedagogia pela Universidade Vale do Acaraú (UVA), hoje faz especialização na instituição de ensino superior privada Universidade Luterana do Brasil (ULBRA). Cursou o Ensino Fundamental em escolas públicas e escolinhas particulares. O médio foi todo cursado em escola pública.

Rosa diz que sempre quis ser professora e que tem muito orgulho de sua profissão. Para ela, o esforço serviu de referência para outros membros da 
família que "entenderam que não devem deixar de estudar". Depois dela (que foi muito influenciada por uma tia professora), outros familiares seguiram "seu exemplo" e se dedicaram à profissão docente, como a irmã e primos. A profissão lhe proporcionou autonomia e condições para tocar a vida "sem depender de ninguém", ainda que diga não se sentir segura por não ser concursada no sistema. A profissão tem sentido muito particular para Rosa: fez com que tivesse coragem de deixar o primeiro marido, que a impedia de estudar. Os estudos e o trabalho docente funcionaram para ela como um recurso de sobrevivência fora do casamento e de dignidade por "abandonar um homem que não lhe respeitava".

A infância foi vivida até os seis anos de idade na Ilha das Onças ${ }^{12}$. Morava às margens do Igarapé chamado São João. A família, diz ela, sempre foi muito carente; o pai era seringueiro e trabalhava como meeiro. Nessa época a maior parte da produção ficava com o dono do terreno, o que acabava por colocar sua família em condições miseráveis. Sua mãe, que estava gestante do quarto filho, cobrava do marido melhores condições de vida.

$\mathrm{Na}$ Ilha das Onças, Rosa passou por acidente muito grave. O pai, depois de recolher o látex na mata, colocava-o para esquentar até que o material formasse uma grande bola. Em seguida, jogava-o em uma lata com água. A professora, ainda menina, à época com apenas 2 anos de idade, pôs o pequeno pé dentro desse recipiente e teve o membro gravemente lesionado. Depois do acidente, o pai muda-se do lugar e se torna pescador.

Com o apoio da avó e de um tio que morava em uma ilha em frente à Cotijuba, a Ilha de Paquetá, a família conseguiu arrendar um terreno e mudar de lugar, o que ocorreu em uma embarcação precária que quase naufraga. O pai começou a trabalhar e quando tudo parecia melhorar, Rosa voltou a ter problemas com o pé e precisou passar oito meses em Belém. Quando melhorou foi morar na casa de parentes na Ilha de Cotijuba para continuar seus estudos.

Posteriormente, foi morar com uma família, onde trabalhava como babá. Passou a ter uma vida diferente, podia brincar e estudar; recebeu todo o apoio dessa família até a sétima série. Ela já estava crescida quando lhe arrumaram um emprego de meio período, e Rosa foi morar com outra tia. Nesse momento, voltou a enfrentar problemas de saúde e precisou novamente interromper os estudos. Recuperada, passou a estudar no período da noite, cursando a quarta etapa. Aos 16 anos de idade, foi vítima de estupro, por um sobrinho da família para a qual trabalhou como babá.

Para tentar superar a violência sofrida, Rosa continuou estudando; decidiu frequentar a igreja, época em que conheceu o pai de seus filhos. Já cursava o primeiro ano do magistério quando engravidou da primeira filha aos 17 anos.

12 Ilhota que faz parte do arquipélago de Guajará. 
Para o relacionamento com o marido, projetou expectativas frustradas. Tempos depois, interrompeu os estudos por pressões do companheiro. $\mathrm{O}$ relacionamento tornou-se difícil, especialmente porque era proibida de estudar. Abandonou o marido com dois filhos, e ainda foi recriminada pelos pais por ter se separado. O pai a chamava de "perdida" e a acusava de envergonhá-lo (ROSA, 2010a).

Pressionada pela família, reconciliou-se com o marido. Parou de estudar em 1989 e só retornou à escola em 1993. Desde então passou a procurar emprego. Sua boa aparência, diz ela, contribuiu para ser admitida em uma concessionária. Desta vez o marido exigiu que ela largasse o emprego. Acatou a exigência, mas continuou estudando com a ajuda de uma irmã com necessidades especiais que a auxiliava com os dois filhos.

Terminou o terceiro ano do magistério e recebeu apoio do prefeito de Belém para a formatura. Em 1997, no mês de maio, foi contratada pela Semec. Após tantos obstáculos, seus sonhos (ela afirma) começavam a se realizar. Para que isso acontecesse (ela sempre reforça) contou com a ajuda de muitas pessoas, mas especialmente de uma professora do curso de magistério. Dela recebeu muito incentivo para superar os traumas de sua vida, especialmente a violência sexual.

Contratada, retornou à ilha para trabalhar. Voltava agora como professora. Decidiu separar-se definitivamente do marido que, em suas palavras, "a consumiu bastante" (ROSA, 2010c). Iniciou assim o seu trabalho na Ilha de Jutuba. "As portas se abriram" (ROSA, 2010c), segundo ela, e teve a oportunidade de conhecer várias pessoas, como a Secretária de Educação do Município. Esses contatos a ajudaram a continuar os estudos e permanecer no magistério. Rosa diz que "ama o que faz"; "ama olhar para as crianças e vê-las alegrarem-se quando descobrem a leitura e o aprendizado".

Depois disso, uma nova jornada começou. Foi cursar Pedagogia. Alugou uma casa e foi morar com os filhos. Passou dois anos trabalhando na Ilha de Jutuba. Em 1999 foi morar no município de Paragominas para trabalhar, mas acabou retornando para a Semec. Voltou a trabalhar nas ilhas de Belém, desta vez na Escola da Ilha Flexeira. Em 2000 foi trabalhar na Escola da Ilha de Jamací, onde desenvolve suas atividades até hoje. Começou uma nova vida, casou-se de novo, e com o apoio do atual companheiro não parou de estudar e trabalhar. Fez o curso de Pedagogia na UVA. O primeiro semestre concluiu em Benevides, município próximo à cidade de Belém. Depois pediu transferência para a capital, onde se formou.

Hoje Rosa se considera uma pessoa realizada. É avó de dois netos, casada e adotou uma filha. Continua a desenvolver seu trabalho nas ilhas de Belém e diz que sua trajetória foi de muita luta, mas que obteve bons resultados. Atualmente mora no Distrito de Icoaraci, próximo de Belém, e se desloca todos os dias para a ilha a fim realizar o trabalho que diz gostar, apesar do baixo salário, das condições desfavoráveis e da instabilidade no emprego. 


\section{Considerações finais}

No texto de Michelle Perrot, intitulado "Minha história das mulheres", em que a autora traça um perfil das condições e lutas dos diversos grupos de mulheres na França, verificamos que naquele país as mulheres camponesas, que não suportavam mais a opressão masculina do homem do campo, ao vislumbrar na formação instruída uma alternativa para sair daquela condição, tal qual as professoras nascidas nas ilhas, encontraram no ofício de professora primária uma saída e para isso passaram a ocupar as carteiras das escolas normais. E, assegura Perrot (2007, p. 114), que este "foi, para muitas, um formidável impulso".

No caso particular das professoras das ilhas de Belém, "tornar-se professora" exige um profundo mergulho na complexidade sociológica em que a menina se constitui enquanto profissional da docência porque esta "escolha" está imbricada às condições de subjugação às quais as mulheres da Amazônia de um modo geral foram assujeitadas ao longo da sua história local e à formação escolar deficiente nos interiores da Amazônia. A rigor, tais mulheres professoras fazem parte de um grupo de mulheres exploradas da região, oriundas de famílias submetidas à condição de extrema pobreza.

Desde a colonização, na Amazônia, as mulheres (excetuadas as relações estabelecidas entre índios e índias) foram tratadas como objeto sexual à disposição dos homens, isto tanto em relação às mulheres índias destribalizadas, quanto em relação às mulheres brancas enviadas pelo reino e que cruzaram o atlântico por não se adequarem às regras morais e cristãs de Portugal, especialmente as prostitutas e as judias, como nos esclarece Silva (2001; 2002). O sistema de honra e vergonha do Brasil colonial, que vicejou por aproximadamente três séculos, do Seiscentos ao Oitocentos, teve, especialmente no Norte, reverberação ao longo do século XX, depois da República. Portanto, na segunda metade do Novecentos, momento em que as professoras desta pesquisa nasceram, ainda se vivia resquícios desse sistema de honra e vergonha no qual ocultar o defloramento, por exemplo, ainda era uma prática vigente. Supõe-se que, por conta desta prática de uso e abuso do corpo da mulher na região, amparado por esse sistema sedimentado pela cultura cristã, a violência sexual contra meninas esteja tão presente entre nós. É por isso que Rosa (2010b), vítima de violência sexual (como Hortência), e mesmo da promovida pelo marido, se preocupa com as crianças das ilhas ao dizer que "é muito comum o abuso contra criança naquele espaço".

Na capitania do Grão-Pará, como nos esclarece Domingues (2001), a Coroa portuguesa ao longo do século XVIII promoveu uma migração maciça de 
homens para ocupar o território amazônico. Para isto, espalhou pela metrópole "folhetos de propaganda" que visavam noticiar entre a plebe que as terras do Pará eram um "paraíso na terra" e ofereceu "regalias de fixação" para quem se dispusesse a embarcar e se instalar no lugar. Aos "dotes" oferecidos pela Coroa somaram-se incentivos de uma política de casamento entre portugueses e índias ou mestiças. Desse modo, El-Rei expede em 4 de abril de 1755 um alvará régio que determinava que os vassalos luso-brasileiros casados com índias recebessem "um machado, uma foice, um ferro de cova, uma enxada, uma peça de bretanha e sete varas de estopa", além das terras concedidas, regalias fiscais e privilégios sociais. Os degradados que vieram trataram, assim, de sequestrar mulheres índias de suas aldeias e possuí-las à força para caracterizar o dito casamento com a filha-da-terra. Para Del Priore (2009) todas as estratégias estabelecidas no sentido de submeter a mulher na colônia fazia parte de um projeto normatizador metropolitano para as populações femininas que inscreveu a mulher na história do poder.

Boxer, um historiador inglês especialista em império português, não vacila em dizer no livro "A mulher na expansão ultramarina ibérica" que o colonizador português tratou as mulheres índias como prostitutas. Para Boxer (1977), a violação contra a mulher promovida pelo português institui o machismo e os preconceitos raciais na sociedade colonial brasileira.

No caso particular das professoras das ilhas, todas mestiças, temporalmente distantes há mais de séculos das representações e relações sociais entre homens e mulheres vividas na Amazônia, a exploração sexual e o racismo são temas presentes e fortes em suas narrativas. É como se a exploração perversa e a violência vividas pelas índias da região e por mulheres brancas que cruzaram o atlântico, assim como a exploração colonial interna tão presente no passado recente da Amazônia, ecoassem nas vidas narradas pelas professoras; mas como isto se articula à docência? Em meio a condições de escolarização tão pouco favoráveis, onde "ser professora" não se coloca em nenhuma hipótese como opção, a profissão docente se transforma, no caso dessas professoras, em uma alternativa, ainda que precária, de ultrapassar a linha da exclusão, da exploração e da própria colonização, já que seus corpos continuam sendo usados como há muito $^{13}$. Para estas mulheres, ascender à condição de docentes significa, antes de tudo, proteger-se da violência sexual da infância e da vida adulta. Afinal,

13 Em "Desejo colonial: hibridismo em teoria, cultura e raça", Young (2005) demonstra que o desejo sexual é a forma mais radical de colonialismo, pois o outro, o colonizado, inferior por natureza, se tornou, histórica e culturalmente, objeto obsessivo de fantasia transgressora do sexo que reforçava sua superioridade ao fertilizar a raça inferior e promover a evolução da civilização na terra. 
quem vai ter coragem de "mexer" com a professora? Para estas professoras a docência promoveu, portanto, não apenas uma ascensão econômica, mas, e principalmente, uma ascensão moral.

Ao ter contato com as professoras Hortência e Rosa foi inevitável fazer dissociações com a experiência de Fontana (2005), que apresenta narrativas de seis docentes que com ela conviveram, em encontros semanais, para discutir a prática pedagógica cotidiana em suas condições de produção no interior da escola. Tais dissociações serviram para corroborar o quanto o vínculo entre o feminino e a docência na Amazônia possui sentidos muito particulares, distantes de "uma vontade de seguir a carreira da mãe" ou "de redimensionar os projetos que o pai sonhou", ainda que as narrativas das professoras emirjam carregadas de docilidade, abnegação, vocação e sacrifício como em muitos outros lugares do território nacional. No nosso caso, a docência é assumida pela mulher como um recurso de sobrevida e é por isso que ela acaba por ocupar um lugar quase sagrado na sua existência, assim como a igreja. Não por acaso, as duas professoras que nos narram suas histórias são frequentadoras assíduas dos cultos de suas religiões: católica e evangélica. Mantendo uma relação estreita com a religião, como há séculos (LOURO, 2008), a docência entre as professoras das ilhas acontece a partir das experiências em cultos religiosos.

Hortência e Rosa são dois tipos-ideais dentre as 8 (oito) professoras que residem ou já residiram nas ilhas. Como conceitua Max Weber (1995), o tipo-ideal é um modelo abstrato que, quando usado como padrão de comparação, nos permite observar o mundo real de uma forma mais clara e mais sistemática. As vidas dessas 2 (duas) professoras em relação a outras nos possibilitam ver mais amplamente o sentido que a docência toma em suas existências e o significado político desse grupo de professoras no contexto de um sistema educacional tão desigual, com oportunidades de escolarização tão diversas e que, de certa forma, não atende às aspirações de uma educação republicana como apregoada na constituição brasileira e na Lei de Diretrizes e Bases da Educação Nacional. Também nos ajudam a entender o sentido moral e econômico do trabalho dessas mulheres no contexto de precariedade da subsistência familiar da qual são oriundas. Na verdade os temas não econômicos tratados na recolha das histórias de vida em muito explicam a direção dessas mulheres ao encontro da docência como profissão e meio de provimento da família.

O caso do ingresso precário das professoras das ilhas no sistema da Semec na condição de prestadoras é um exemplo de como as conquistas alcançadas a duras penas (como a formação superior em instituições particulares) são parciais e estão longe de tirá-las da condição de submetimento em que a história tratou de colocá-las. Tal condição se concretiza na prática quando as professoras se tornam reféns das universidades particulares, que oferecem formação precária, e 
não conseguem prepará-las para a aprovação nos concursos públicos da Semec. Esta situação, no plano do psicológico, produz na professora um sentimento de inferioridade, de incapacidade, que é minimizada quando ela consegue (como acontece com Hortência) se tornar liderança na comunidade e se envolver com as suas conquistas e, até, por conta disso, se manter no sistema, mesmo como prestadora. Em depoimento, Hortência (2010) disse que só não foi afastada porque a comunidade "não deixa", porque a própria comunidade sabe que a professora que não é do lugar não se dedica tanto quanto ela. Este envolvimento oferece um novo aparelhamento à professora, mas mesmo assim não é suficiente para torná-la mais senhora de seu destino e promover a superação da exclusão à qual a mulher mestiça, especialmente a mulher da Amazônia, vem sendo submetida, como acontece com toda a mulher da ralé (CARNEIRO; ROCHA, 2009).

Por fim, identificamos que há um campo de investigação aberto para novos estudos sobre a professora, a docência e gênero na região amazônica, especialmente sobre a mulher e a história da região. Particularmente percebemos que é preciso investir esforços em estudos sobre a história da docência no Pará: as primeiras professoras, as primeiras escolas para meninas, as regras de conduta impostas às mulheres e as transgressões produzidas por elas, as práticas discursivas que aliam docência e mulher na região.

\section{REFERÊNCIAS}

BELÉM. Secretaria Municipal de Coordenação Geral do Planejamento e Gestão - SEGEP. Anuário Estatístico do Município de Belém, v. 11, 2006.

BOXER. C. R. A mulher na expansão ultramarina. Lisboa: Livros Horizontes, 1977.

CARNEIRO, Maria Tereza; ROCHA, Emerson. Do fundo do buraco: o drama social das empregadas domésticas. SOUZA, Jessé (Org.). A ralé brasileira: quem é e como vive. Belo Horizonte: Editora UFMG, 2009.

DEL PRIORE, Mary. Ao sul do corpo: condição feminina, maternidades e mentalidades no Brasil colônia. São Paulo: Editora UNESP, 2009.

DOMINGUES, Ângela. Famílias portuguesas na colonização do norte brasileiro. In: SILVA, Maria Beatriz Nizza da (Org.). Sexualidade, família e religião na colonização do Brasil. Lisboa: Livros Horizontes, 2001. p. 215-221.

DUBY, Georges; PERROT, Michelle. História das mulheres - século XX. Porto: Afrontamento, 1991. 
FIGUEIREDO, Napoleão. Os "bichos" que curam: os animais e a medicina de "folk" em Belém do Pará. Boletim do Museu Paraense Emílio Goeldi-Antropologia. Belém, v. 10, n. 1, p. 75-91, 1994.

FONTANA, Roseli A. Cação. Como nos tornamos professoras? 3. ed. Belo Horizonte: Autêntica, 2005.

GALVÃO, Eduardo. Santos e Visagens: um estudo da vida religiosa de Itá, Amazonas. São Paulo: Nacional, 1976.

HORTÊNCIA. Sua história de vida: depoimento [27 de jul. de 2010]. Entrevistadora: Lenise Ferreira. Ilha do Mosqueiro-PA, 2010. MP4 (01h13).

INSTITUTO HISTÓRICO E GEOGRÁFICO DO PARÁ (IBGE). Disponível em: <http:// www.ibge.gov.br/cidadesat/painel/>. Acesso em: 15/04/2012.

LOURO, Guacira Lopes. Mulheres na sala de aula. In: DEL PRIORE (Org.). História das mulheres no Brasil. São Paulo: Contexto, 2008. p. 443-481.

PERROT, Michelle. As mulheres ou os silêncios da história. Bauru: Edusc, 2005.

. Minha história das mulheres. São Paulo: Contexto, 2007.

ROSA. Sua história de vida: depoimento [ $1^{\circ}$ de julho de 2010]. Entrevistadora: Aline da Silva Santos Costa. Icoaraci, Belém-PA, 2010a. Gravação em MP3 (108 min).

. História de vida de uma professora ribeirinha [8 de julho]. Entrevistadora: Aline da Silva Santos Costa. Icoaraci, Belém-PA, 2010b. Gravação em MP3 (120 min). . História de vida de uma professora ribeirinha [15 de julho]. Entrevistadora: Aline da Silva Santos Costa. Icoaraci, Belém-PA, 2010c. Gravação em MP3 (170 min). SCOTT, Joan. História das mulheres. In: BURKE, Peter (Org.). A escrita da história: novas perspectivas. São Paulo: Editora da UNESP, 1992.

SILVA, Maria Beatriz Nizza da (Org.). Sexualidade, família e religião na colonização do Brasil. Lisboa-PT: Livros Horizontes, 2001.

SILVA, Maria Beatriz Nizza da. Donas e plebéias na sociedade colonial. Lisboa: Editorial Estampa, 2002.

WEBER, Max. Metodologia das ciências sociais. 2. ed. São Paulo: Cortez, 1995.

YOUNG, Robert J. C. Desejo colonial: hibridismo em teoria, cultura e raça. São Paulo: Perspectiva, 2005.

Texto recebido em 03 de agosto de 2014. Texto aprovado em 10 de agosto de 2014. 